\title{
Perceptions about the biology of Rhipicephalus (Boophilus) microplus among milk producers in Divinópolis, Minas Gerais
}

\author{
Percepção dos produtores de leite de Divinópolis, Minas Gerais, \\ sobre a biologia do Rhipicephalus (Boophilus) microplus \\ Christiane Maria Barcellos Magalhães da Rocha ${ }^{1 *}$; Romário Cerqueira Leite ${ }^{2}$; Fábio Raphael Pascoti Bruhn ${ }^{1}$; \\ Antônio Marcos Guimarães ${ }^{1}$; John Furlong ${ }^{3}$ \\ ${ }^{1}$ Laboratório de Epidemiologia , Departamento de Medicina Veterinária, Universidade Federal de Lavras - UFLA \\ ${ }^{2}$ Escola de Veterinária, Universidade Federal de Minas Gerais - UFMG \\ ${ }^{3}$ Centro Nacional de Pesquisa de Gado de Leite, Empresa Brasileira de Pesquisa Agropecuária - EMBRAPA
}

Receveid February 22, 2011

Accepted April 19, 2011

\begin{abstract}
One hundred semi-systematized interviews were applied with the aim of surveying the perceptions of milk producers in the municipality of Divinópolis, Minas Gerais regarding the biology of the tick Rhipicephalus (Boophilus) microplus. Content analysis was conducted on each of the variables surveyed and their descriptions, highlighting the higher frequencies in order to construct profiles of perceptions about each of the matters surveyed. In addition, each of the producers was categorized regarding their readiness to proceed with efficient control, from the assessment of their responses. Among the variables surveyed were the tick lifespan, duration of parasitic life, time of greatest incidence, survival in pastures and egg-laying volume. These questions are considered important for defining the knowledge needed for rational combat. It was concluded that the information needed for adopting effective practices to combat ticks was insufficient among the milk farm properties in Divinópolis. Moreover, the producers interviewed had a good perception of what they observed in their daily routine, but did not have complementary information about the tick life cycle.
\end{abstract}

Keywords: Rhipicephalus (Boophilus) microplus, tick, interview, milk producer, knowledge.

\section{Resumo}

Foram aplicadas 100 entrevistas semissistematizadas com o objetivo de levantar a percepçáo dos produtores de leite do município de Divinópolis, Minas Gerais, sobre a biologia do carrapato Rhipicephalus (Boophilus) microplus. Foi feita "análise de conteúdo" de cada uma das variáveis levantadas e sua descrição com destaque das maiores frequências para a construçáo de perfis de percepçáo sobre cada um dos aspectos levantados. Além disso, cada um dos produtores foram categorizados quanto a estar ou náo apto a proceder um controle eficiente pela avaliação de suas respostas. Algumas das variáveis levantadas foram tempo de vida do carrapato, tempo de vida parasitária, época de maior incidência, sobrevivência nas pastagens e volume de postura, questóes consideradas importantes para se definir o conhecimento necessário a um combate racional. Concluiu-se que as informações necessárias à adoção de práticas efetivas de combate aos carrapatos são insuficientes nas propriedades de leite de Divinópolis e, ainda, que os produtores entrevistados têm boa percepçáo no que se observa no dia a dia e náo têm informaçóes complementares sobre o ciclo de vida dos carrapatos.

Palavras-chave: Rhipicephalus (Boophilus) microplus, carrapato, entrevista, produtor de leite, conhecimento.

\footnotetext{
*Corresponding author: Christiane Maria Barcellos Magalhães da Rocha

Laboratório de Epidemiologia, Departamento de Medicina Veterinária,

Universidade Federal de Lavras - UFLA, CP 3037,

CEP 37200-000, Lavras, MG, Brasil

e-mail: rochac@dmv.ufla.br; Support by: FAPEMIG
} 


\section{Introduction}

The state of Minas Gerais is located at the center of the southeastern region of Brazil and has boundaries with all the states in this region, as well as with states in the central-western and northeastern regions. It is the state with the largest effective dairy cattle herd in the country, with 3.1 million head out of the 15 million head of cattle in the country in 2007 (ANUALPEC, 2008).

A large proportion of the milk produced in this state comes from small family-run properties with low use of technology, often because of deficiencies in transmission and adaptation of the technologies that exist.

For a long time now, the technical information needed for rational control over the tick Rhipicephalus (Boophilus) microplus has existed in Minas Gerais, in the form of strategic dipping or spraying. The aim of such measures is to drastically diminish the infestation of pastures and consequently the animals, with lower frequency of pesticide application over the year (FURLONG, 1993). However, the milk producers continue to carry out dipping or spraying without following any technical criteria and without taking into consideration any aspects of tick biology (ROCHA, 1996; ROCHA et al., 2006).

It has been seen that there is a great distance between the technical knowledge available and the methods used to combat ticks on milk-producing farm properties (LEITE; LIMA, 1982; ROCHA, 1996; LEITE; ROCHA, 1999). The solution for this problem requires knowledge of the situation among cattle-rearers nationwide, in order to establish the causes of this imbalance. This would involve ascertaining the information that producers would need to absorb these strategies and the viability of incorporating such strategies into different real situations. Hence, the present study had the aim of surveying the knowledge that producers have regarding the biology of $R$. (B.) microplus and assessing their perceptions, as a basis for achieving effective combat against the parasite.

\section{Material and Methods}

To gather data, interviews were conducted in 1993 and 1994 , using questionnaires that had previously been constructed and tested, in order to gather information to characterize the milkproducing farm properties in the municipality of Divinópolis, Minas Gerais (20 8' 20" S and $44^{\circ} 53^{\prime} 2^{\prime \prime} \mathrm{W}$ ) and to ascertain the producers' perceptions regarding cattle ticks. The complete study can be seen in Rocha (1996).

The producers interviewed were chosen by means of random sampling of the milk-producers' register of the Minas Gerais Institute of Agriculture and Livestock-rearing (IMA) for the year 1993, along with information from the Agriculture Department of Divinópolis. This municipality is located in microregion 186 of the state of Minas Gerais, with an area of $716 \mathrm{~km}^{2}$ and a mean annual temperature of $23{ }^{\circ} \mathrm{C}$. The rural properties are organized into communities and the great majority consist of small producers, which were characterized by the size of the landholding, the effective herd size and the production and productivity.
The total number of properties surveyed was 318 , distributed in 18 rural communities, and 134 interviews were conducted, distributed proportionally among the communities. In the present study, 100 questionnaires were analyzed, after taking into account the exclusion criteria (inconsistencies and pretests).

The qualitative methodology, going from the construction of the questionnaires and processing the interviews, to the data analysis and description of the results, was done in accordance with Rocha (1996), based on Minayo (1993), Selltiz et al. (1967), Triviños (1987) and Gil (1991).

Using the information obtained from the interview questionnaires, a database was constructed. Thus, for each question that was asked, the data were described according to how the individuals in the group varied, with emphasis on what was typical (greater frequency) in the study sample, in order to extract profiles and conclusions. The open responses were categorized using content analysis (MINAYO, 1993) and it was sought to understand the logic in the interviewees' explanations.

To assess the knowledge that would be necessary for rational combat against ticks, the various questions relating to tick biology were looked at using indicators for this purpose that would explain the perceptions regarding the parasite lifespan and free-living lifespan, egg-laying volume, seasonality, acceptable infestation level and other characteristics.

In a second type of qualitative analysis, all the responses obtained from the same producer were classified as correct or incorrect in relation to what is recommended by the literature, by means of content analysis (MINAYO, 1993). The analysis on responses considered to be correct or incorrect was reviewed by specialists in order to provide backing for the authors' decisions. According to the number of correct responses, the producer was categorized as having good, moderate or poor knowledge, using the following criteria: poor- producers who did not show any knowledge of tick biology and were not in a position to do any planning to combat them; moderate- producers who had insufficient knowledge of tick biology to control them; good - producers who showed that they had the knowledge needed to carry out rational tick control.

\section{Results and Discussion}

The profile of the farm properties in Divinópolis was mainly characterized by small landholdings of up to 50 ha, destined only for milk production by crossed cattle, with a mean of eight liters per cow and $100 \mathrm{~L}$ in total, per day. Most of the farms used family labor, were the only source of family income and had been in the same hands for more than ten years. The owners had completed no more than elementary school level and were aged over 45 years. The level of technology encountered was low (ROCHA, 1996).

All the results obtained are summarized in Table 1, which demonstrates what can be considered to be the producers' profile, from the responses that were given with greater frequency.

It was sought to determine the level of tick infestation that could be tolerated per animal per day, according to the producers' perceptions, by asking about the number of large ticks (teleogines) that the animal would tolerate per day without health impairment. Twenty-two percent said that any quantity of large ticks would 
Table 1. Frequency of responses at the interviews applied to milk producers in Divinópolis, Minas Gerais, 1993-94.

\begin{tabular}{|c|c|c|c|c|c|c|c|c|}
\hline \multirow[t]{2}{*}{ Information $^{2}$} & \multicolumn{8}{|c|}{ Responses in order of frequency ${ }^{1}$} \\
\hline & $1^{\text {st }}$ place & $\%$ & $2^{\text {nd }}$ place & $\%$ & $3^{\text {rd }}$ place & $\%$ & $4^{\text {th }}$ place & $\%$ \\
\hline $\begin{array}{l}\text { Infestation that could be tolerated } \\
\text { per animal per day }{ }^{1}\end{array}$ & Less than 50 & 42 & $\begin{array}{c}\text { Any quantity of large } \\
\text { ticks }\end{array}$ & 22 & $\begin{array}{c}\text { Between } 50 \text { and } \\
100\end{array}$ & 22 & Others & 14 \\
\hline Animal body region most affected ${ }^{2}$ & Udder & 81 & Neck & 40 & Axillae & 30 & Others & - \\
\hline $\begin{array}{l}\text { Causes of greater infestation per } \\
\text { body region }{ }^{2}\end{array}$ & $\begin{array}{l}\text { Places with greater } \\
\text { protection }\end{array}$ & 48 & $\begin{array}{l}\text { Skin softer, looser, } \\
\text { smoother }\end{array}$ & 24 & Close to ground & 21 & Others & - \\
\hline Length of survival in pasture ${ }^{1}$ & More than 4 months & 49 & Don't know & 16 & $\begin{array}{l}\text { The longer, the } \\
\text { more they breed }\end{array}$ & 16 & Others & - \\
\hline Time of occurrence $^{1}$ & Whole year & 97 & Others & 3 & - & - & - & - \\
\hline Time of greatest incidence ${ }^{1}$ & Rainy period & 51 & Dry period & 45 & No difference & 3 & Don't know & 1 \\
\hline Egg-laying volume $^{1}$ & Don't know & 36 & Around 1000 & 12 & Around 100 & 12 & Around 2000 & 5 \\
\hline Predators $^{2}$ & Known & 98 & Not known & 2 & - & - & - & - \\
\hline Pasture types favoring ticks ${ }^{2}$ & Brachiaria grass & 42 & Don’t know & 24 & $\begin{array}{c}\text { Cleared and clean } \\
\text { pasture }\end{array}$ & 11 & - & - \\
\hline Pasture types not favoring ticks ${ }^{2}$ & Don't know & 53 & Meloso/ gordura grass & 25 & Natural & 9 & $\begin{array}{c}\text { Provisional } \\
\text { (Jaraguá grass) }\end{array}$ & 7 \\
\hline Greater resistance of zebus ${ }^{1}$ & Known & 95 & Not known & 5 & - & - & - & - \\
\hline
\end{tabular}

1) Percentage corresponds to absolute number; 2) Each interviewee could select more than one option.

harm the cattle, because when a number of large ticks was found, there would be a much larger quantity of small ticks already feeding off the animal. Some respondents said that after the big ticks, there would be less harm, because the main damage came from the blood-sucking performed by the tick to grow. Four percent said that there would have to be around 500 or more ticks, or a lot of ticks without defining the quantity. Practically all the respondents made it clear that they did not know with any exactness. However, it was seen that the great majority (64\%) responded that fewer than 50 ticks would already cause harm to the animal, which was similar to what was observed by Leite and Rocha (1999). This shows that the level of concern regarding high infestation per animal was not very far from the literature, in which 30 to 40 ticks per animal was believed to be harmful (FURLONG, 1993).

The region of the body cited as concentrating the greatest quantity of ticks was the udder (81\%). Following this were the neck, axillae, groin, ears, perineum and belly $(40,30,26,23,20$ and $17 \%$, respectively). Other regions appeared less frequently. The results showed that there was a good perception of the regions of the body that were most affected.

The owners were then asked about the reasons why ticks had become attached mainly in these sites. The most frequent response (48\%) was than this was "the site that was most protected from the sun, rain and the animal's attempts to relieve itching; most comfortable for the parasites, where there were most wrinkles". Six percent said that they had no idea. Other responses were given less frequently.
The responses that cited that the greatest infestation was in regions of the body that the animal could not access using its mouth are supported by the findings of D'Andrea et al. (2006). These authors affirmed that there was greater resistance to tick attachment in areas where self-cleaning with the tongue was performed. Thus, it is logical that ticks would manage to become attached to the animals in places that are more protected, thereby escaping from this mechanism. It is also very logical to affirm that the greatest infestation would occur in regions of the body that are closer to the ground, given that the infesting larvae originate from the soil. However, regarding some of the responses given, there is no data in the literature that would confirm or refute the affirmations. There are some studies that have correlated the infestation with the characteristics of the skin or fur in the most infested locations (VERÍSSIMO et al., 2002).

With regard to the duration of the parasitic life of the tick, the producers were asked about "how long ticks remained on the cows". Among the interviewees, $16 \%$ stated categorically that they did not know. From the frequencies of the other responses, it can be concluded that even those who responded differently knew little about the parasitic phase. Two percent of the interviewees thought that the time was indefinite, almost as if it were "eternal".

The duration of the parasitic life of $R$. (B) microplus reported in the literature is a mean of between 18 and 26 days (GONZALES, 1974; FURLONG, 1993; ROCHA, 2000). Thirty-nine percent of the interviewees came close to this in their responses, giving durations or either 15 to 21 days or 22 to 35 days. Interviewees who said that the parasitic phase lasted for less than seven days $(25 \%)$ seemed to support this observation mainly 
on the perception of rapid engorgement of teleogines during the final stage, which can occur overnight (WHARTHORN; UTECH, 1970), or furthermore, because of the rapidity of growth of the neogines, which start to become more visible in day-to-day management and have a mean duration of five days (GONZALES, 1974). This showed that there was total lack of knowledge of the cycle of $R$. (B.) microplus among this group of producers, although some logic was shown in the daily observations.

When asked about "the lifespan of ticks", most of the respondents $(43 \%)$ showed that they did not know. The mean free-living period of $R$. (B.) microplus in central Brazil has been reported to be around 45 to 75 days, and its total life cycle as around 63 to 101 days on average (FURLONG, 1993). Only another $14 \%$ of the interviewees came close to reality, with responses of between three and four months of life, thus demonstrating that the rural producers had little knowledge about the life cycle of ticks.

Regarding the survival of ticks in the pastures, the producers were asked "how much time would it be necessary for an area of pasture to remain without cattle (or other animals) for it to be free from ticks?". Among the interviewees, 49\% said it was more than four months, because they had experience of this, or had seen this on neighboring farms. In fact, the larvae can remain without feeding for more than six months (GONZALES, 1974). Other responses were given at low frequencies. The interviewees were mostly smallholders and therefore were not in a position to leave any of their pastures without animals. Experiences that have given this indication of survival have come from places that formerly were occupied by cattle and were then used to plant a crop, or were vacant plots for which there was uncertainty regarding whether it had not been grazed and/or used by any animals. Especially because of these types of experience cited above, $16 \%$ of the interviewees said that "the longer the pasture remains unused, the more the ticks breed". This view gave indications for these owners that it was not necessary to have animals in the area for ticks to survive, and some even went as far as stating that ticks were (part of nature", thus also believing in spontaneous generation.

In relation to the time of occurrence, $97 \%$ of the property owners had a perception that ticks could be present throughout the year. This is really the case in southeastern Brazil, where there are four generations of $R$. (B.) microplus per year (SOUZA et al., 1988; FURLONG, 1993; VERÍSSIMO et al., 1997).

The producers were asked about the months of greatest tick infestation in the animals. These responses were categorized as the rainy and dry seasons. The months from October to March were considered to be the rainy season and April to September as the dry season. Only $6 \%$ of the responses did not fit completely into one of these categories, and these were categorized only when they mostly fitted into the above ranges. Out of the 100 interviewees, 51 responded that the animals became more infested in the rainy months, while 45 said this occurred during the dry months. Thus, the seasonal variation of ticks was perceived by the great majority of the producers, although there was some discrepancy regarding the time of greatest incidence. In southeastern Brazil, the greatest incidence has been found to be during the rainy season, i.e. the southern hemisphere summer and autumn, since the higher humidity and temperature during this period favors occurrences of ticks (CAMPOS JÚNIOR; OLIVEIRA, 2005).
One confounding factor for the producers may have been that they did not differentiate between Amblyomma cajennense and $R$. (B.) microplus, considering that these two species have very different biological cycles.

A large portion of the interviewees (36\%) responded that they did not know the egg-laying volume of a female tick, while 5\% said "around 2000" and 7\% said "between 3000 and 5000", thus coming close to reality, which is between 2000 and 3000 eggs/ laying/teleogine (ROCHA, 1999). From the responses, it was perceived that the producers did not have any knowledge about the egg-laying volume per female. Many of the respondents said that they really did not know that ticks reproduced in this manner.

The producers said that the hosts other than cattle that could also be parasitized by ticks were dogs and horses (52\%), or just horses (34\%). In addition to these, the following have been cited in the literature: goats, sheep, deer, humans and others (GONZALES, 1974; BITTENCOURT et al., 1990).

The producers' perceptions regarding the existence of different tick species that parasitize different hosts were surveyed. Four of them did not answer this question because they had already said that they did not perceive any other hosts. Forty-five percent of the producers said that there was no difference between the ticks that parasitized one species and another, while 50\% perceived that there were differences between tick species. What may have caused difficulty in recognizing species specificity was the fact that A. cajennense also parasitizes cattle, along with the various phases of life of each species.

With regard to differentiation between species and phases of life of ticks, only $4 \%$ of the property owners said that they did not know. Forty-seven percent said that "big ticks were the same as small ones that had grown", while $49 \%$ said that they were "different types". Over the course of the parasitic life of ticks, they not only grow but also change their cuticle. For this reason, there is morphological differentiation from one phase to another, which led to a certain degree of confusion among the producers.

The interviewees (98\%) had a good perception regarding tick predators. The main predators cited were hens and anis, and birds in general. All the responses given were correct.

Brachiaria decumbens was recognized by $42 \%$ of the producers as a type of forage that favors tick infestation. This is the pasture grass type that most aids the development of $R$. (B.) microplus (THOMPSON et al., 1978; AYCARDI et al., 1984; FARIAS et al., 1986; BARROS; EVANS, 1989; VERÍSSIMO et al., 1997). Several of the interviewees cited not a pasture grass type but, rather, pasture conditions that seemed to give ticks greater protection, such as "dirty pasture, longer grass in the pasture, reserved pasture" or hot and damp places, or even cleared and clean pasture.

Most of the producers (53\%) had no knowledge regarding the pasture characteristics that might affect tick survival. Among the types that were cited with greater frequency were capim melosol capim gordura grass (Melinis minutiflora) (25\%), natural pasture (9\%) and jaraguá grass (Hyparrhenia rufa) (7\%). The only one for which there has been support in the literature is Melinis minutiflora (THOMPSON et al., 1978; AYCARDI et al., 1984; FARIAS et al., 1986; BARROS; EVANS, 1989).

Out of the 100 producers interviewed, 95 perceived a difference in tick resistance between zebu and taurine cattle. This difference 


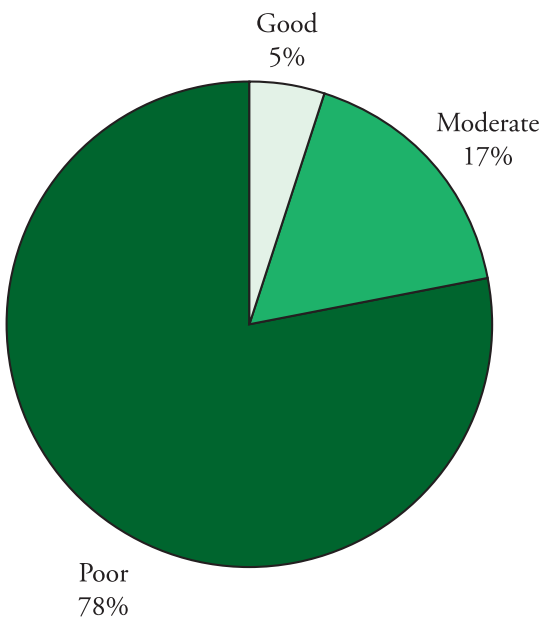

Figure 1. Categories of milk producers in Divinópolis, MG, regarding knowledge of the biology of Rhipicephalus (Boophilus) microplus that is needed for strategic tick control.

was also recognized among crossed cattle, as inversely proportional to the amount of Friesian blood that they had. In this respect, it was often necessary to clarify the difference between "zebu cattle" and "European cattle". When this occurred, the producers stated that the Friesian breed was the most sensitive one. This information has been well known through research in Brazil for many years (VILLARES, 1941; LEMOS et al., 1985; VERÍSSIMO et al., 2002).

It was noted that the producers has concerns regarding high tick infestations. They perceived the regions of the body where the cattle were most infested and their causes. They did not know about the tick life cycle and its relationship with pasture; they were divided regarding differentiation between tick species and recognition of their stages of parasitic life; but they knew about tick predators and the differences in resistance to ticks among cattle breeds. In other words, characteristics that could not be observed every day and depended on complementary information were not perceived. This was also found among producers in Passos, Minas Gerais (ROCHA et al., 2006).

Individual analysis on the questionnaires, with the aim of ascertaining which of the producers would have the necessary information for combating ticks indicated that $95 \%$ of the producers did not have the knowledge that would be needed to proceed with rationally combating the tick $R$. (B.) microplus (Figure 1).

These producers continue to combat ticks in the traditional way (ROCHA, 1996; ROCHA et al., 2006), and lack of knowledge about the tick cycle is probably one of the reasons for this. In order to proceed with any form of systematized control, it is necessary to know about the biology of the pest that is to be combated, so that viable ways of doing this and efficient strategies can be established. When such control becomes obligatory among producers, it is fundamental that they should have the correct technical information for the action, including any matters that arouse their interest to seek further information.

Thus, it can be seen that social factors (including cultural factors) that determine disease morbidity need to be taken into consideration and should be worked on, in seeking to improve tick control in Brazil.

\section{Conclusions}

The specific information needed for adopting effective tick control practices among the milk-producing properties in Divinópolis, Minas Gerais, is insufficient. The producers have no knowledge of the biology of $R$. (B.) microplus. They perceive characteristics that can be observed in their day-to-day routine, but they do not have the technical information that is fundamental to tick control.

Systematized provision of information on ticks and their control, through courses within the technical assistance network for these producers, folders, booklets and recent forms of communication like the internet or social communication networks, should be implemented or intensified so that producers can be educated with the aim of achieving satisfactory tick control.

Tick-borne diseases have to be brought into the national healthcare agenda, so that they cease to be a problem exclusively for producers in seeking to improve control measures.

\section{References}

ANUALPEC. Anuário da Pecuária Brasileira. 1 ed. São Paulo: Instituto FNP, 2008. 332 p.

AYCARDI, E. et al. Boophilus microplus tick burdens on grazing cattle in Colombia. Tropical Animal Health and Production, v. 16, n. 2, p. 78-84, 1984. PMid:6485100. http://dx.doi.org/10.1007/BF02239849

BARROS, A. T. M.; EVANS, D. E. Ação de gramíneas forrageiras em larvas infestantes do carrapato dos bovinos, Boophilus microplus. Pesquisa Veterinária Brasileira, v. 9, n. 1-2, p. 17-21, 1989.

BITTENCOURT, A. J. et al. Comportamento do B. microplus (CANESTRINI, 1887) (Acari) em infestaçōes artificiais e naturais em diferentes hospedeiros. Arquivo Universidade Federal Rural do Rio de Janeiro, v. 13, n. 2, p. 173-182, 1990.

CAMPOS JÚNIOR, D. A.; OLIVEIRA, P. R. Avaliação in vitro da eficácia de acaricidas sobre Boophilus microplus (CANESTRINI, 1887) (Acari: Ixodidae) de bovinos no município de Ilhéus, Bahia, Brasil. Ciência Rural, v. 35, n. 6, p. 1386-1392, 2005.

D'ANDREA, L. A. Z. et al. Condição imunológica de bovinos das raças Holandesa e Nelore frente a Babesia bovis e B. bigemina em duas regióes do Estado de São Paulo. Pesquisa Veterinária Brasileira, v. 26, n. 2, p. 74-78, 2006

FARIAS, N. A. R.; GONZALES, J. C.; SAIBRO, J. C. Antibiose e antixenose entre forrageiras e larvas de carrapato-de-boi. Pesquisa Agropecuária Brasileira, v. 21, n. 12, p. 1313-1320, 1986.

FURLONG, J. Controle do carrapato dos bovinos na região Sudeste do Brasil. Cadernos Técnicos da Escola de Veterinária da UFMG, n. 8 , p. 49-61, 1993.

GIL, A. C. Métodos e técnicas de pesquisa social. São Paulo: Editora Atlas S.A., 1991. 207 p.

GONZALES, J. C. O carrapato do boi: vida, resistência e controle. São Paulo: Mestre Jou, 1974. 101 p.

LEITE, R. C.; LIMA, J. D. Fatores sanitários que influenciam na criação de bezerros. Arquivos da Escola de Veterinária da UFMG, v. 34, n. 3, p. 485-492, 1982. 
LEITE, R. C.; ROCHA, C. M. B. M. Contagens de carrapatos em bovinos no momento do banho carrapaticida em rebanhos leiteiros do Município de Divinópolis/MG. Arquivos Brasileiros de Medicina Veterinária e Zootecnia, v. 51, n. 1, p. 41-42, 1999.

LEMOS, A. M. et al. Comparative performance of six Holstein-Friesian $\mathrm{x}$ Guzera grades in Brazil. 3. Burdens of Boophilus microplus under field conditions. Animal Production, v. 41, n. 2, p. 187-191, 1985. http://dx.doi.org/10.1017/S0003356100027847

MINAYO, M. C. S. O desafio do conhecimento: Pesquisa qualitativa em saúde. 2. ed. São Paulo: HUCITEC; Rio de Janeiro: ABRASCO, 1993. 269 p.

ROCHA, C. M. B. M. Caracterizaçáo da percepçáo de produtores de leite de Divinópolis/MG sobre o carrapato Boophilus microplus e fatores determinantes das formas de combate utilizadas. 1996. 205 f. Dissertação (Mestrado)-Universidade Federal de Minas Gerais, Belo Horizonte.

ROCHA, C. M. B. M. Aspetos relevantes da biologia do Boophilus microplus. Boletim técnico da UFLA, n. 32, p. 5-24, 1999.

ROCHA, C. M. B. M. Importância do Boophilus microplus, Canestrini, 1887 (Acarina, Ixodidae) no processo produtivo do leite. Boletim Técnico da UFLA, n. 35, p. 5-20, 2000.

ROCHA, C. M. B. M. et al. Percepção dos produtores de leite do município de Passos, MG, sobre o carrapato Boophilus microplus (Acari: Ixodidae), 2001. Ciência Rural, v. 36, n. 4, p. 1235-1242, 2006.
SELLTIZ, C. et al. Métodos de pesquisa nas relaçóes sociais. São Paulo: Editora da Faculdade de São Paulo, 1967. 687 p.

SOUZA, A. P.; GONZALES, J. C.; RAMOS, C. I. Variação sazonal de Boophilus microplus no Planalto Catarinense. Pesquisa Agropecuária Brasileira, v. 23, n. 6, p. 627-630, 1988.

THOMPSON, K. C.; ROA, J. E.; ROMERO, T. N. Anti-tick grasses as the basis for developing practical tropical tick control packages. Tropical Animal Health and Production, v. 10, n. 1, p. 179-182, 1978. PMid:705900. http://dx.doi.org/10.1007/BF02235337

TRIVIÑOS, A. N. S. Introduçáo à pesquisa em Ciências Sociais: a pesquisa qualitativa em educaçáo. São Paulo: Atlas, 1987. 175 p.

VERÍSSIMO, C. J. et al. Haircoat characteristics and tick infestation on Gyr (Zebu) and crossbred (Holstein x Gyr) cattle. Archivos de Zootecnia, v. 51, n. 195, p. 389-392, 2002.

VERÍSSIMO, C. J. et al. Resistência e susceptibilidade de bovinos leiteiros mestiços ao carrapato Boophilus microplus. Boletim da Indústria Animal, v. 54, n. 2, p. 1-10, 1997.

VILLARES, J. B. Climatologia zootécnica III. Contribuição ao estudo da resistência e susceptibilidade genética dos bovinos ao Boophilus microplus. Boletim da Industria Animal, v. 4, n. 1, p. 60-86, 1941.

WHARTHORN, R. H.; UTECH, K. B. W. The relation between engorgement and dropping of Boophilus microplus (CANESTRINI) (Ixodidae) to the assessment of tick numbers on cattle. Australian Journal of Entomology, v. 9, n. 3, p. 171-182, 1970. http://dx.doi. org/10.1111/j.1440-6055.1970.tb00788.x 